\title{
Impacts of a decadal drainage disturbance on surface-atmosphere fluxes of carbon dioxide in a permafrost ecosystem
}

\author{
Fanny Kittler $^{1}$, Ina Burjack ${ }^{1}$, Chiara A. R. Corradi ${ }^{2}$, Martin Heimann ${ }^{1,3}$, Olaf Kolle ${ }^{1}$, Lutz Merbold ${ }^{4,6}$, \\ Nikita Zimov $^{5}$, Sergey Zimov ${ }^{5}$, and Mathias Göckede ${ }^{1}$ \\ ${ }^{1}$ Biogeochemical Systems, Max Planck Institute for Biogeochemistry, Jena, Germany \\ ${ }^{2}$ University of Tuscia, Viterbo, Italy \\ ${ }^{3}$ Division of Atmospheric Sciences, Department of Physics, University of Helsinki, Finland \\ ${ }^{4}$ ETH Zurich, Department of Environmental Systems Science, Institute of Agricultural Sciences, Zurich, Switzerland \\ ${ }^{5}$ North-East Science Station, Pacific Institute for Geography, Far-Eastern Branch of Russian Academy of Science, \\ Chersky, Republic of Sakha (Yakutia), Russia \\ ${ }^{6}$ Mazingira Centre, International Livestock Research Institute (ILRI), Nairobi, Kenya \\ Correspondence to: Fanny Kittler (fkittler@bgc-jena.mpg.de)
}

Received: 4 April 2016 - Published in Biogeosciences Discuss.: 22 April 2016

Revised: 31 August 2016 - Accepted: 6 September 2016 - Published: 23 September 2016

\begin{abstract}
Hydrologic conditions are a major controlling factor for carbon exchange processes in high-latitude ecosystems. The presence or absence of water-logged conditions can lead to significant shifts in ecosystem structure and carbon cycle processes. In this study, we compared growing season $\mathrm{CO}_{2}$ fluxes of a wet tussock tundra ecosystem from an area affected by decadal drainage to an undisturbed area on the Kolyma floodplain in northeastern Siberia. For this comparison we found the sink strength for $\mathrm{CO}_{2}$ in recent years (2013-2015) to be systematically reduced within the drained area, with a minor increase in photosynthetic uptake due to a higher abundance of shrubs outweighed by a more pronounced increase in respiration due to warmer near-surface soil layers. Still, in comparison to the strong reduction of fluxes immediately following the drainage disturbance in 2005, recent $\mathrm{CO}_{2}$ exchange with the atmosphere over this disturbed part of the tundra indicate a higher carbon turnover, and a seasonal amplitude that is comparable again to that within the control section. This indicates that the local permafrost ecosystem is capable of adapting to significantly different hydrologic conditions without losing its capacity to act as a net sink for $\mathrm{CO}_{2}$ over the growing season. The comparison of undisturbed $\mathrm{CO}_{2}$ flux rates from 2013-2015 to the period of 2002-2004 indicates that $\mathrm{CO}_{2}$ exchange with the atmosphere was intensified, with increased component fluxes (ecosystem respiration and gross primary production) over
\end{abstract}

the past decade. Net changes in $\mathrm{CO}_{2}$ fluxes are dominated by a major increase in photosynthetic uptake, resulting in a stronger $\mathrm{CO}_{2}$ sink in 2013-2015. Application of a MODISbased classification scheme to separate the growing season into four sub-seasons improved the interpretation of interannual variability by illustrating the systematic shifts in $\mathrm{CO}_{2}$ uptake patterns that have occurred in this ecosystem over the past 10 years and highlighting the important role of the late growing season for net $\mathrm{CO}_{2}$ flux budgets.

\section{Introduction}

Northern high-latitude permafrost landscapes contain over $1000 \mathrm{Pg}$ of organic carbon in the upper $3 \mathrm{~m}$ of the soil (Hugelius et al., 2014), equaling approximately $50 \%$ of the global belowground carbon storage. This vast amount of organic carbon has been accumulated due to the slow decomposition rates of organic matter under low temperatures and anoxic conditions during the last two glacial cycles (Zimov et al., 2009). With the sustainability of these huge carbon pools being dependent on future climate conditions (Kaufman et al., 2009; Kirschbaum, 1995; Serreze et al., 2000), there is a high potential for global feedback if the permafrost carbon reservoir is destabilized under future climate conditions (Beer, 2008). One potential outcome could be that the 
soil carbon previously locked away in permafrost deposits could be released into the atmosphere as $\mathrm{CO}_{2}$ or $\mathrm{CH}_{4}$ as a consequence of changes in soil temperature and moisture conditions (Schuur et al., 2008). However, model simulations show a wide range of permafrost responses to climate change (Koven et al., 2011; Schaefer et al., 2011). Empirical studies on the sensitivity of permafrost to environmental drivers are urgently needed to corroborate comprehensive Earth system models. Here we report on the effects of a decadal drainage experiment on the $\mathrm{CO}_{2}$ exchange in a typical northern Siberian tundra ecosystem.

Over the last few decades observations in the Arctic have shown that, as a result of global warming, temperatures have risen faster than those observed over the Northern Hemisphere as a whole (ACIA, 2004; SWIPA, 2011). This tendency, primarily driven by ice-albedo effects (Curry et al., 1995), is expected to continue, and climate models project a strong future high-latitude warming (IPCC, 2013). In permafrost ecosystems, higher temperatures will lead to increased active layer thickness and thus favor substrate availability for microbial decomposition and enhanced release of greenhouse gases (GHGs) to the atmosphere (Schuur et al., 2008). At the same time, warmer conditions may lead to prolonged vegetation periods with increased photosynthetic uptake, while higher soil temperatures may stimulate $\mathrm{CO}_{2}$ production through enhanced soil respiration (Flanagan and Syed, 2011). Ice wedge degradation (Jorgenson et al., 2006; Lawrence et al., 2008; Payette et al., 2004) is also expected, which has the potential to dramatically alter the geomorphology and hydrology of permafrost landscapes (Liljedahl et al., 2016). Through this process, a relatively homogeneous area could be transformed into a network of small water channels that drain water away from the remaining patches of soil surface. The resulting changes in the spatiotemporal patterns of soil water availability could potentially trigger significant shifts in ecosystem characteristics, such as soil thermal regime or vegetation and microbial community composition. These changes, in turn, would alter carbon cycle processes; for example, changing aerobic conditions in the top soil layers have the potential to change preferred pathways for microbial decomposition of methane (Merbold et al., 2009; Zona et al., 2009, 2010). Such changes would promote $\mathrm{CO}_{2}$ efflux due to higher soil respiration rates (Flanagan and Syed, 2011; Olivas et al., 2010).

The complexity of potential positive and negative feedback loops between climate change and carbon cycling in the Arctic leads to considerable uncertainties concerning the effects of long-term shifts in the carbon budget of an Arctic permafrost ecosystem caused by changing environmental conditions. Most studies to date on the net effect of such a disturbance on biogeochemical processes in the Arctic have focused on short-term perturbations (Bret-Harte et al., 2013; Merbold et al., 2009); however, it is likely that the long-term effects of this disturbance may differ greatly from the short-term effects that immediately follow the dis- turbance event (Shaver et al., 1992). Studies addressing longterm ( $>10$ years) manipulation effects for the high latitudes are rare. In one such study, Lamb et al. (2011) found that 16 years of a combined fertilization and warming experiment in Canada's high Arctic tundra showed limited effects on GHG fluxes and soil chemistry or biochemistry but strong increases in plant cover and height. A 2-decade warming experiment in Alaskan tundra revealed increased plant biomass and woody dominance, indirectly increased winter soil temperature, and increased net ecosystem carbon storage (Sistla et al., 2013). In wetting and fertilizing experiments in the open heath of Zackenberg, an area in northeastern Greenland, the soil water supply was increased for 14 years, and occasional fertilizer pulses were added, resulting in increased soil respiration rates during summer and decreased $\mathrm{CO}_{2}$ efflux in autumn (Christiansen et al., 2012). Results from a summer warming and wetting treatment in northeastern Greenland over 10 years indicated increased $\mathrm{CO}_{2}$ uptake in response to altered environmental conditions; this increase was mostly cause by photosynthetic uptake of carbon (Lupascu et al., 2014). In a long-term (20 years) fertilization experiment in Alaskan tundra, Mack et al. (2004) increased nutrient availability, which lead to a net ecosystem loss of carbon, with increased aboveground plant production outweighed by carbon and nitrogen losses from deep soil layers. Due to the multiple and unclear results of available environmental manipulations, additional and particularly long-term experiments are crucially needed.

To improve the current understanding of links between carbon fluxes and long-term hydrologic disturbance in Arctic permafrost ecosystems, a monitoring program was established near Chersky in northeastern Siberia in 2013 $\left(68.75^{\circ} \mathrm{N}, 161.33^{\circ} \mathrm{E}\right)$. In this study, we present growing season $\mathrm{CO}_{2}$ fluxes for two eddy-covariance towers running in parallel over a disturbed tundra ecosystem (i.e., one with a drainage ditch ring installed in 2004) and a control tundra ecosystem, respectively. We directly compare $\mathrm{CO}_{2}$ flux rates between both sites for three growing seasons (2013-2015) to evaluate the net effect of the long-term drainage on the carbon cycle. A comparison of disturbed and control flux rates between historic (2002-2005) and recent (2013-2015) datasets allows us to assess the combined effect of this disturbance and a changing climate. In both cases, we focus on the net $\mathrm{CO}_{2}$ flux between ecosystem and atmosphere, as well as its major components fluxes, i.e., gross primary productivity (GPP) and ecosystem respiration $\left(R_{\text {eco }}\right)$. We also analyzed the seasonality of flux rates over the course of the growing season. 


\section{Methods and datasets}

\subsection{Site description}

The research site was located in a floodplain of the Kolyma river near the city of Chersky $\left(68.75^{\circ} \mathrm{N}, 161.33^{\circ} \mathrm{E}\right)$, in the northeastern part of Siberia, Russia. Situated south of the Arctic tree line within the floodplain of the Kolyma river, this area was subject to annual flooding in spring, leading to a common vegetation structure that was characterized by sedges, shrubs, and sphagnum mosses (Merbold et al., 2009) and defined as a wet tussock tundra. The mineral soil of the permafrost and active layer was influenced by the sediment transport of the river and was classified as silty loam (Corradi et al., 2005). The transition period between the snowcovered and snow-free seasons was strongly influenced by the flooding in late spring, which in most years led to standing water on the site as a result of snowmelt and rising water levels in the nearby river. Development of the vegetation in the flooded sections was therefore usually delayed compared to dry areas where snow melt is followed by rapid greening. Continuous daylight and continental air masses (which are warm, dry, and from the S to SE) characterized the summer (i.e., June-August). Overall, in 2014, the mean annual temperature was $-10^{\circ} \mathrm{C}$, with daily means ranging from $-49^{\circ} \mathrm{C}$ in January to $22^{\circ} \mathrm{C}$ in July. The mean annual precipitation was about $172 \mathrm{~mm}$, with nearly $50 \%$ of this precipitation occurring during the summer. As a result of limited light and low temperatures, the growing season was mainly restricted to 3 months of the year, from mid-June to the end of August.

\subsection{Disturbance experiment}

The experimental concept of the disturbance was designed to modify the local water regime and soil moisture conditions. The manipulation consisted of a $200 \mathrm{~m}$ diameter drainage ditch that connected to the nearby river through a channel of $\sim 300$ m length (Merbold et al., 2009). This drainage system was installed in autumn 2004 and is still in place today, altering the water table depth and thus significantly modifying biogeochemical and biogeophysical site characteristics during the last decade. For the recent observation program, two observation sites were chosen: one within the drainage ring (thus covering the areas affected by lowered groundwater levels) and another serving as a control site (close by but far enough away to represent natural conditions unaffected by the disturbance). Since both sites had to be close enough to share a power supply, the two observation sites were $\sim 600 \mathrm{~m}$ apart (Fig. 1).

\subsection{Instrumentation setup}

To monitor ecosystem-scale $\mathrm{CO}_{2}$ fluxes, two eddycovariance systems were installed in July 2013. One tower (Tower $1,68.61^{\circ} \mathrm{N}$ and $161.34^{\circ} \mathrm{E}$ ) was placed within the drainage area (Fig. 1, blue shaded area), so that its foot-

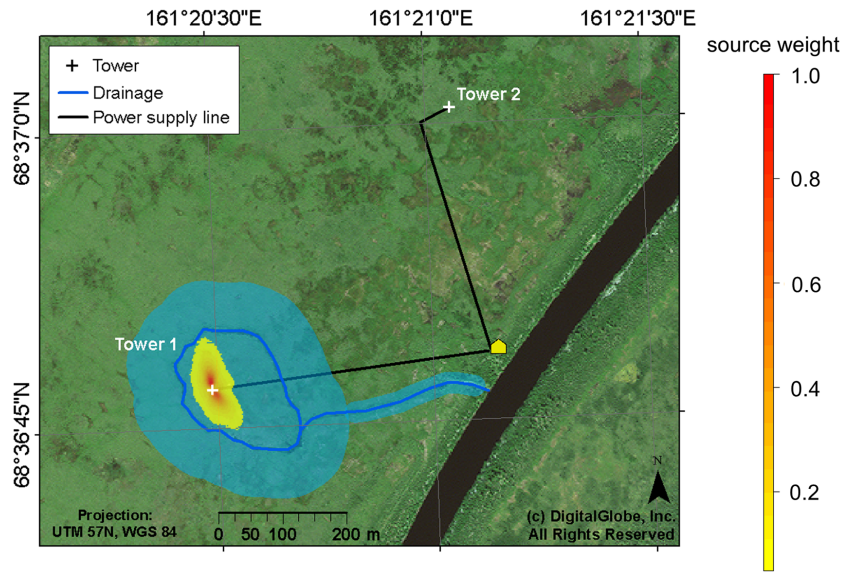

Figure 1. Overview of observational setup and site facilities on a wet tussock tundra near Chersky. The circular drainage ditch and drainage channel (blue lines) were installed in 2004 and are still in place today, altering the water table depth (blue shaded area outline the approximate area affected by the drainage). The image also depicts the towers (white crosses), power lines (black lines), and generator housing (yellow hut). The red-yellow colored area around Tower 1 indicates the weighted source function of footprints averaged over all stability classes from 15 May to 14 September 2014.

print primarily covered areas affected by reduced groundwater levels. The control tower (Tower $2,68.62^{\circ} \mathrm{N}$ and $161.35^{\circ} \mathrm{E}$ ) represented natural conditions (Fig. 1). Data acquisition started 13 July 2013 for Tower 1 and 16 July 2013 for Tower 2.

The ground under both towers had an elevation of approximately $6 \mathrm{~m}$ a.s.l., with an average vegetation height of $0.7 \mathrm{~m}$ in the surrounding area during peak growing season. Each tower was equipped with a heated sonic anemometer (uSonic-3 Scientific, by Metek GmbH, Elmshorn, DE) that monitored the three-dimensional wind field and the sonic temperature at the top of the towers (at heights of 4.91 and $5.11 \mathrm{~m}$ for Tower 1 and 2, respectively). During the first summer season of the experiment, the $\mathrm{CO}_{2}$ and $\mathrm{H}_{2} \mathrm{O}$ flux densities were measured exclusively using open-path sensors (LI7500 by LI-COR Biosciences Inc., NE, USA). These gas analyzers were placed next to the sonic anemometer, with a sensor separation of $0.38 \mathrm{~m}$ at both towers. In 2014, new closedpath gas analyzers (FGGA by Los Gatos Research Inc., CA, USA) for monitoring GHG mixing ratios were added to the setup. These systems consisted of an inlet placed next to the sonic anemometer (vertical sensor separation: $0.30 \mathrm{~m}$ ), a sampling line (heated and insulated Eaton Synflex decabon with $6.2 \mathrm{~mm}$ inner diameter and a length of 16.0 and $12.8 \mathrm{~m}$ for Tower 1 and 2, respectively), and an external vacuum pump (N940, KNF). The flow rate of $13 \mathrm{~L} \mathrm{~min}^{-1}$ (ambient pressure) translated into a replacement of sample air in the measurement cell at a frequency of $\sim 2-2.5 \mathrm{~Hz}$. Both openand closed-path analyzers had been running in parallel at Tower 1 since installation, while the open-path analyzer on 
Table 1. Summary of the observed environmental variables available for both towers, including instrumentation and measurement height. Tussock measurements describe the conditions in the middle of the tussock $(0.2 \mathrm{~m}$ to the top of the tussock and $0.2 \mathrm{~m}$ to the soil surface). Heights above the soil surface are indicated as positive numbers; depths below the soil surface are given as negative numbers.

\begin{tabular}{lll}
\hline Environmental variable & Instrumentation & Measurement height (m) \\
\hline Air temperature & KPK 1/6-ME-H38, Mela & 2 and 5 \\
Relative humidity & KPK 1/6-ME-H38, Mela & 2 and 5 \\
Barometric pressure & Pressure transmitter, 61302V, Young & 5 \\
Long/short up/downwelling radiation & CNR4, Kipp \& Zonen & 5 \\
Up/downwelling photosynthetically active radiation & PQS1, Kipp \& Zonen & 5 \\
Precipitation & Tipping bucket rain gauge, Thies & 1 \\
Soil moisture & ML-2x, DeltaT & $-0.08,-0.16$, and tussock \\
Soil temperature & Pt100, YUMO & $-0.04,-0.08,-0.16,-0.32$, \\
& & $-0.64,-1.28$, and tussock \\
\hline
\end{tabular}

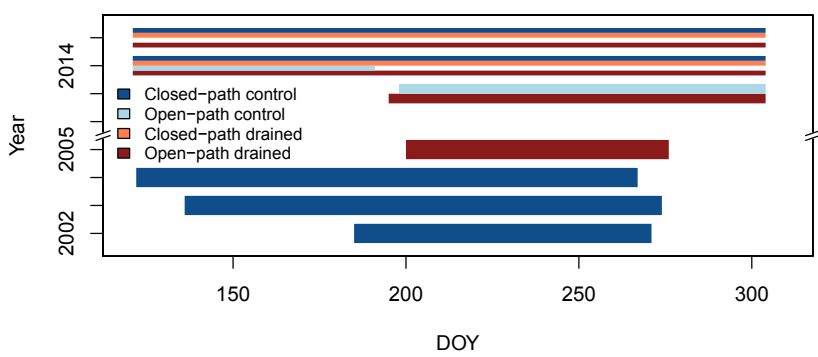

Figure 2. Measurement time frame for the eddy-covariance systems (open-path: LI7500; closed-path: LI6262 and FGGA) of both towers, for both the recent (2013-2015) and historic (2002-2005) observation periods.

Tower 2 was disassembled in July 2014. An overview of the active times for the different gas analyzing systems is given in Fig. 2. Additional instrumentation to monitor environmental variables is listed in Table 1 .

\subsection{Data processing}

The observed meteorological data (Table 1) were collected at $10 \mathrm{~s}$ intervals and stored on a data logger (CR3000, Campbell Scientific) as averages over $10 \mathrm{~min}$ periods. The postprocessing quality control scheme of the meteorological data included a test for failure of the power supply, a test that checks the range of parameters within a certain time window, a flat lining test, and a spike test, as well as tests for identifying malfunctioning sensors and consistency limits. The final dataset was averaged to $30 \mathrm{~min}$ intervals.

For the eddy-covariance towers, the data were collected at a rate of $20 \mathrm{~Hz}$ with analogue output for the gas analyzers. All analog signals were first transmitted to the sonic anemometer, where they were digitized and sent to the site computer jointly with the wind signal. Data acquisition was handled through the software package EDDYMEAS (Kolle and Rebmann, 2007) on a local computer at the field site. The processing of the high-frequency eddy-covariance data was based on the software tool TK3 (Foken and Mauder, 2015), which implements the following major components: for both open- and closed-path gas analyzing systems, the flux processing includes (1) a 2-D coordinate rotation of the wind field, (2) a cross-wind correction (Liu et al., 2001), and (3) a correction for loss in the high-frequency range (Moore, 1986). For the closed-path systems, the greenhouse gas mixing ratios originally recorded as wet mole fractions were converted to dry mole fractions before processing by the TK3 software. To correct losses in the high-frequency range that occur when gases are transferred to the closedpath analyzers through inlet tubes at flow rates much lower than the sampling frequency, cutoff frequencies of 2.5 and $2 \mathrm{~Hz}$ for $\mathrm{CO}_{2}$ and $\mathrm{H}_{2} \mathrm{O}$, respectively, were applied. For data collected by the open-path gas analyzers, the WPL correction (Webb et al., 1980) was applied. To account for the selfheating of the open-path analyzer, a correction was applied following Burba et al.'s (2006) approach for inclined positions $\left(\sim 15^{\circ}\right)$, using an optimized fractionation factor of 0.07 based on high-quality data. This fractionation factor was subsequently used for the data post-processing of all open-path measurements used within the context of the present study.

Our post-processing quality control scheme was based on the quality flagging system initially proposed by Foken and Wichura (1996), which tests data for effects such as stationarity and well-developed turbulence. Afterwards, a set of additional tests was applied to flag implausible data points in the resulting flux time series. These tests included a check for absolute limits for net ecosystem exchange (NEE; $\left.5 \mu \mathrm{mol} \mathrm{m}{ }^{-2} \mathrm{~s}^{-1}<\mathrm{NEE}<-15 \mu \mathrm{mol} \mathrm{m} \mathrm{m}^{-2} \mathrm{~s}^{-1}\right)$, the open-path gas analyzing system status information (gain control maximum $>75$ ), and overall errors in the log file recorded by the sonic anemometer, as well as a comparison of the absolute concentrations of $\mathrm{CO}_{2}$ for the two towers for specific wind directions. This comparison of concentrations was performed to detect potential contamination by the exhaust plume of the generator (based on a more than $5 \%$ difference criterion).

Gap filling and flux partitioning were both based on the so-called marginal distribution sampling method (Reichstein 
et al., 2005), implemented through the $\mathrm{R}$ package REddyProc (https://r-forge.r-project.org/projects/reddyproc/). As there was a pronounced variability of environmental conditions during the growing season, the dataset was split into four different sub-seasons (see Sect. 2.6 for details), with individual gap filling and flux partitioning data pools for each sub-season. The final NEE time series used within the context of the present study were merged from open-path (until April 2014) and closed-path (since April 2014) fluxes.

Data coverage ranged between 60 and $80 \%$ over the different years of eddy-covariance flux measurement using closedpath observations. Gaps were commonly less than a day and distributed equally over all sub-seasons. Longer gaps were caused by flooding events, when the entire system needed to be shut down to avoid damage, or resulted from a laser offset in the closed-path gas analyzer at Tower 1 in 2015.

The flux-partitioning algorithm that splits NEE into GPP and $R_{\text {eco }}$ signals is based on the estimation of the nighttime respiration as a function of temperature and the extrapolation of this relationship for the daytime (Reichstein et al., 2005). In a subsequent processing step, GPP is derived from the difference between NEE and $R_{\text {eco }}$ (for details see Reichstein et al., 2005). The results for the component fluxes GPP and $R_{\text {eco }}$ presented here are therefore not based on direct measurements but rather represent a model-data hybrid product. The performance of this procedure is dependent on a number of user-defined settings, such as the definition of nighttime conditions by setting a radiation threshold (present study: $20 \mathrm{~W} \mathrm{~m}^{-2}$, e.g., Parmentier et al., 2011; Runkle et al., 2013). To address the temperature dependence of $R_{\text {eco }}$, we used air temperature instead of soil temperature. This decision was based on two factors: first, the patterns in nearsurface temperatures were implausible at our site; secondly, higher-quality soil temperatures at $0.08 \mathrm{~m}$ below the surface cannot be correlated to short-term changes in respiration patterns because of a damped diurnal cycle. This decision was based on our observance of implausible patterns in nearsurface temperature measurements at our site, and, because of a damped diurnal cycle, higher-quality soil temperatures at $0.08 \mathrm{~m}$ below the surface cannot be correlated to short-term changes in respiration patterns. During the growing season, air and near-surface soil temperatures are closely linked, and both represent the temperature regime within the soil, driving respiration processes (Lloyd and Taylor, 1994). However, this flux-partitioning approach using air temperature data is limited during the thawing and refreezing periods when energy is not used for heating, but instead for the phase change of ice water, and when soil temperatures do not change relative to air temperatures.

For the statistical analysis of the whole dataset, a linear regression with a moving window of 14 days was used to analyze the peak uptake. An hourly shift was chosen to account for short-term variabilities. Maximum negative slopes were identified as maximum uptake rates while the center of the window represents the day of year (DOY) with the maximum

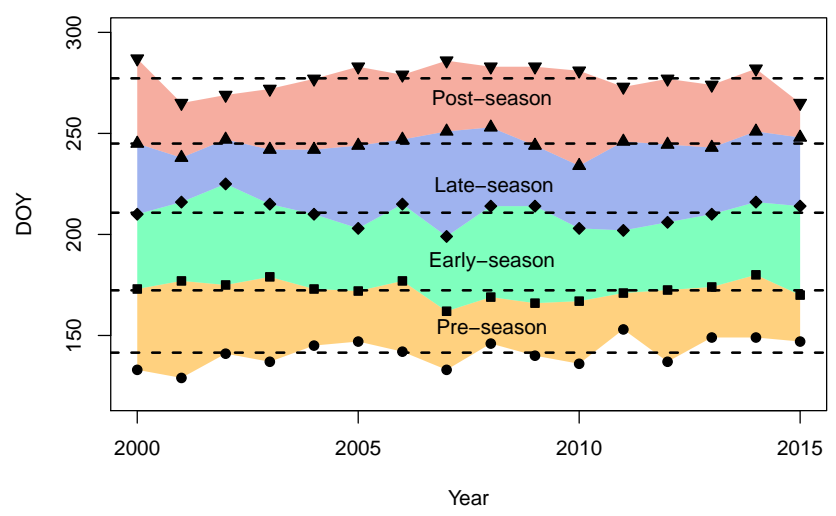

Figure 3. Interannual variability of all key dates with symbols marking the exact date, with lines indicating the overall mean and colored areas representing the resulting sub-season during the growing season. Key dates from bottom to top: start of pre-season (circle), SOS (rectangle), POS (diamond), EOS (standard triangle), and end of the post-season (upside-down triangle). Due to cloud coverage, in 2012 the MODIS data coverage was not high enough to determine the key dates (SOS-POS); these dates are therefore linearly interpolated.

uptake. To determine statistical differences between drained and control site a one-way analysis of variance (ANOVA) was performed to compare the means of the time series. Measurements and thus errors are independent, the data are normally distributed and the variances are equal in most cases. All statistical designs and analysis were performed with the software R (R Core Team, 2014).

\subsection{Historic dataset}

Eddy-covariance measurements were conducted during the 2002-2005 growing seasons in the context of the TCOS Siberia project (Corradi et al., 2005; Merbold et al., 2009, Fig. 2), at the same location that was used for the drainage tower in the new experiment starting 2013. Flux measurements until the end of October 2004 represented an undisturbed tussock tundra (Merbold et al., 2009). After the installation of the drainage channel in autumn 2004, flux measurements at the same location in the subsequent year indicated that this modification in the local water regime resulted in no significant change to the seasonal budgets of net carbon dioxide fluxes (Merbold et al., 2009). However, these trends were based on a single year of observations only and thus did not reflect the long-term effects of such a disturbance.

To facilitate a direct comparison between recent (20132015) and historic (2002-2005) observations, the raw datasets from the period of 2002-2005 were re-processed using the same data processing and quality assessment procedure outlined in Sect. 2.4. This re-processing caused minor changes in the flux rates compared to the values reported in Corradi et al. (2005) and Merbold et al. (2009) because of changed assumptions and inputs when using a different 


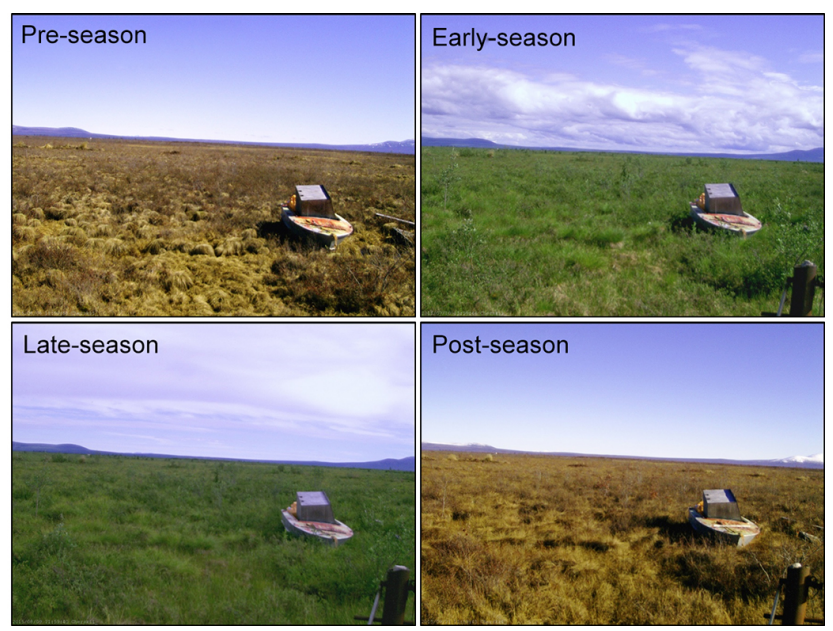

Figure 4. Webcam pictures representing the course of the 2015 growing season. All pictures were taken at noon in the middle of each sub-season: (a) mid-pre-season (6 June), (b) mid-early-season (10 July), (c) mid-late-season (9 August), and (d) mid-post-season (21 September).

flux processing software. However, general patterns in interannual variability of fluxes were not affected. For the data collected in 2004, a parallel run of open- and closed-path gas analyzers resulted in systematic differences in the seasonal dynamics and final budgets (see also Merbold et al., 2009) for $\mathrm{CO}_{2}$ and $\mathrm{H}_{2} \mathrm{O}$ fluxes. These differences remained $\left(R^{2}=0.75\right)$ even after re-processing and applying additional corrections that have since become available (Burba et al., 2006), as well as analyzer-specific corrections. Since the seasonal patterns in the open-path data displayed implausible patterns (e.g., near-zero fluxes at the beginning of the growing season, when dominating positive fluxes are expected) we decided to use only the closed-path data for 2004 in this study. More frequent gaps in the historic dataset compared to the recent dataset were caused by failures in the power supply system, as there was no continuous or stable power supply during this time (Merbold et al., 2009). To compare differences between historic and recent datasets the same statistical approaches as mentioned in Sect. 2.4 were used.

\subsection{Remote sensing and additional data sources}

We used MODIS NDVI (MOD09GQ, MOD13Q1) with both daily and 16-day temporal resolution to analyze the interannual variability in phenology at the observation site. Raw data for the $250 \mathrm{~m}$ daily NDVI products were filtered for outliers based on the 16-day composite NDVI time series, and smoothed using a moving average approach (window size of 10 days). Based on the GreenBrown $\mathrm{R}$ package (Forkel et al., 2013), the following phenological key dates were derived from trends and patterns in the resulting seasonal course of NDVI: start of season (SOS), peak of season (POS), and end of season (EOS), for each year individual. From the tempo-

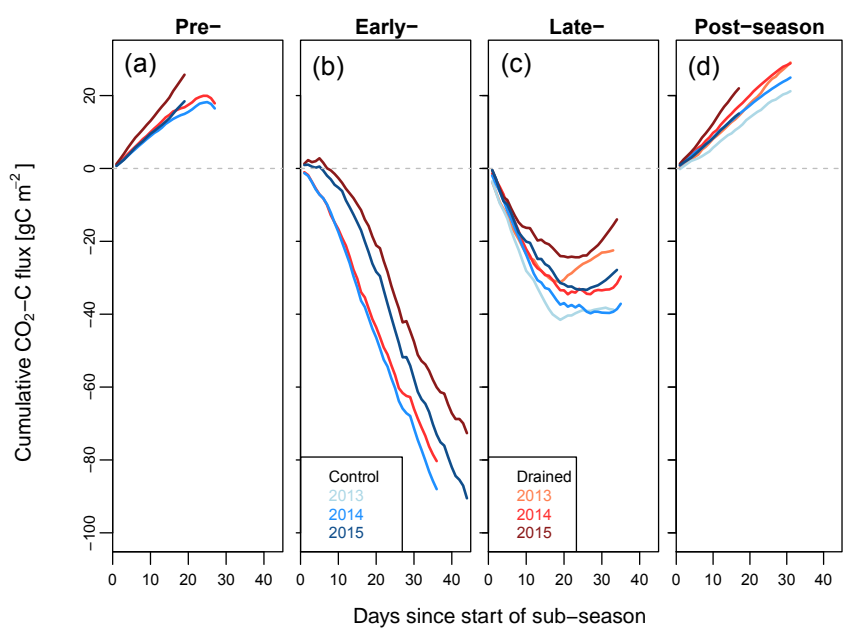

Figure 5. Cumulative $\mathrm{CO}_{2}$ flux budgets for recent (2013-2015) eddy-covariance measurements for both sites (drained is in red, control is blue). A grey line indicates the zero lines with a change from positive (i.e., release) and negative (i.e., uptake) fluxes. For these plots, timestamps have been normalized to account for interannual shifts in phenology. Time series were separated into the four different sub-seasons (see Sect. 2.6) using individual key dates for each year. Time series were then plotted in separate panels, resetting the budgets to zero at the beginning of each sub-season. No measurements are available for the 2013 pre- and early seasons, since measurements started mid-July 2013.

ral trends in MODIS time series of NDVI, the POS is determined by maximum value. For SOS and EOS a threshold of 46 and $59 \%$ of the corresponding POS was taken, respectively. These key dates allowed the growing season to be separated into four distinct sub-seasons: (1) pre-season (until SOS), (2) early season (SOS to POS), (3) late season (POS to EOS), and (4) post-season (after EOS). To mark the beginning of the growing season (start of the pre-season), the first date when the daily mean temperature remained above $4^{\circ} \mathrm{C}$ for 4 consecutive days was used. The end of the growing season (end of the post-season) was set at when there was a MODIS fractional snow cover $>50 \%$. Mean values for SOS, POS, and EOS, as well as year-to-year variability of these key dates within the period 2000-2015, are provided in Fig. 3.

A webcam (CC5MPXWD, Campbell Scientific) provided an additional data source for vegetation characterization. Pictures were taken daily at noon over the course of the growing season. Figure 4 provides an overview of the vegetation dynamics from pre-season (Fig. 4a) towards post-season (Fig. 4d). 


\section{Results}

\subsection{Effects of drainage disturbance on recent carbon fluxes}

Net ecosystem exchange and component fluxes varied considerably between 2013 and 2015 (Figs. 5 and 6). Splitting the time series into sub-seasons allows for an in-depth analysis of the changing impact of the drainage effects on the $\mathrm{CO}_{2}$ flux over the course of the growing season:

\subsubsection{Pre-season}

The pre-season was characterized by a rapid increase in net radiation and rising air temperatures (see Table A1). In the weeks directly following snowmelt, cumulative NEE (Fig. 5a) shows a net loss of $\mathrm{CO}_{2}$ from the system, while photosynthetic uptake is still weak. Both the drained and control study sites are continuous sources for $\mathrm{CO}_{2}$, and only minor differences are observed between treatment sites and years. Averaged over all available time series, we found net releases of $\sim 19( \pm 4) \mathrm{gCO}_{2}-\mathrm{C} \mathrm{m}^{-2}$ over the course of 20-30 days.

\subsubsection{Early season}

With the onset of strong photosynthetic uptake linked to rapidly greening plant biomass (Fig. 4b), both the timing and initial rates of net $\mathrm{CO}_{2}$ uptake are very similar at the two sites (Fig. 5b). Still, over time, deviations in uptake rates become obvious. For instance, by the end of the 2015 subseason the drained site showed a net uptake of $\sim 20 \mathrm{gCO}_{2}-$ $\mathrm{C} \mathrm{m}^{-2}$ less than the control site. The analysis of component fluxes (Fig. 6b) indicates that the difference in NEE can be attributed to the higher release of $\mathrm{CO}_{2}$ via ecosystem respiration at the drained site, while photosynthetic uptake is close to uniform between sites for all years (Fig. 6b).

\subsubsection{Late season}

Early-season differences in NEE between the drained and control sites continue during the late season. With the onset of vegetation senescence both areas shift from a net sink to a net source of $\mathrm{CO}_{2}$ (Fig. $5 \mathrm{c}$ ), but for all data years the control site has a higher net cumulative uptake of $\mathrm{CO}_{2}$ from the atmosphere. The timing of the peak cumulative budget (i.e., the date when the ecosystem shifts from a net sink to a net source of $\mathrm{CO}_{2}$ ) differs by year and seems to be strongly influenced by air temperature conditions in August, with the latest peaks coinciding with the warmest temperatures (data not shown). Differences in cumulative NEE between the two treatments amount to $\sim 12( \pm 4) \mathrm{gCO}_{2}-\mathrm{C} \mathrm{m}^{-2}$; again, the effect was primarily driven by higher respiration rates in the drained area. The observed slight difference in GPP between the drained and control sites was non-uniform between years (Fig. 6c).

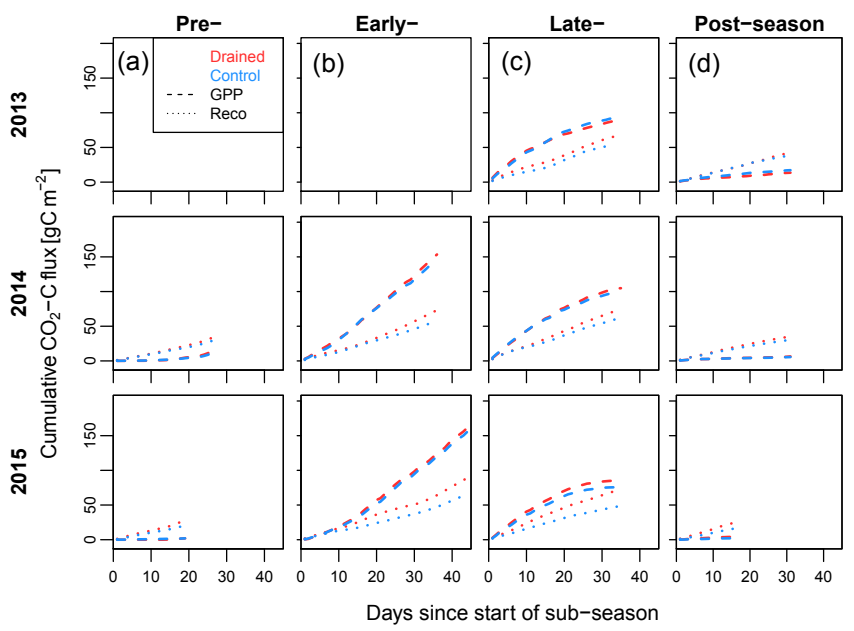

Figure 6. Cumulative ecosystem respiration $\left(R_{\mathrm{eco}}\right.$, dotted line $)$ and gross primary production (GPP, dashed line) from 2013 (upper panel) to 2015 (bottom panel) for both treatments (red and blue respectively as in Fig. 5). Time axes within this plotting scheme are identical to those used in Fig. 5.

\subsubsection{Post-season}

Differences in the cumulative carbon budgets between both sites further increased, as evidenced by the consistently higher cumulative values presented for the drained site (Fig. 5d). Both sites are continuous sources for $\mathrm{CO}_{2}$ during this sub-season, with decreased incoming radiation and air temperature conditions leading to the senescence of the last remaining active vegetation patches. This results in near-zero assimilation fluxes and thus no diurnal NEE cycle. Higher respiration rates in the drained area lead to higher net $\mathrm{CO}_{2}$ emissions (Fig. 6d).

Across all of the sub-seasons, our results demonstrate that the control site was a stronger sink for $\mathrm{CO}_{2}$ than the drained site. The majority of the observed $\mathrm{CO}_{2}$ flux differences are caused by higher ecosystem respiration rates at the drained site, especially during the early and late seasons, while only negligible differences in GPP are observed. Over the entire growing season, the cumulative uptake at the control site is $20-40 \mathrm{gCO}_{2}-\mathrm{C} \mathrm{m}^{-2}$ higher than at the drained site, with significant differences (ANOVA, $p<0.05$ ) between treatments in both 2013 and 2015 (in 2014 no significant difference in cumulative NEE between the sites was found). Daily mean flux rates over the course of the 2015 growing season are shown in Fig. A1a in Appendix A.

\subsection{Comparison of the recent (2013-2015) and historic (2002-2005) datasets}

Data coverage between the historic and recent observation periods varied considerably, with measurement starting dates ranging from the beginning of May to mid-July and end dates differing by up to 2 months (Fig. 2). To facilitate a di- 

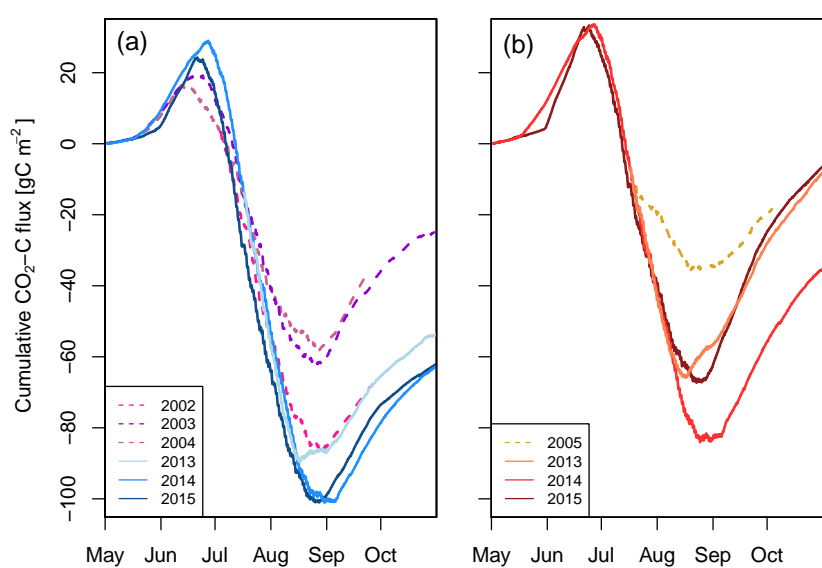

Figure 7. Recent (2013-2015) and historic (2002-2005) cumulative $\mathrm{CO}_{2}$ budgets separated into disturbance regimes: (a) control area; (b) drained area.
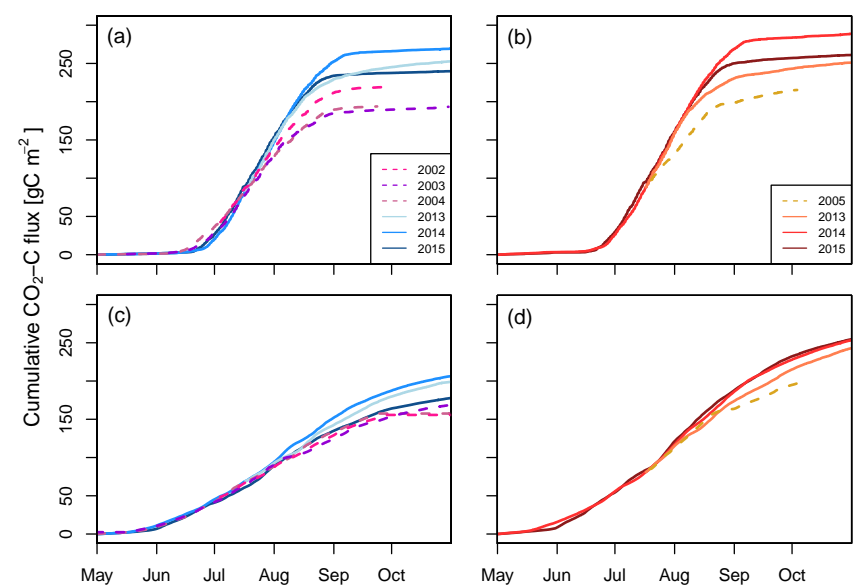

Figure 8. Cumulative signal of recent (2013-2015) and historic (2002-2005) gross primary production (GPP, top panel a and b) and ecosystem respiration ( $R_{\mathrm{eco}}$, lower panel $\mathbf{c}$ and $\left.\mathbf{d}\right)$, separated into disturbance regimes: (a) and (c) control area; (b) and (d) drained area. Time axes within this plotting scheme are identical to those used in Fig. 7.

rect comparison of the carbon budgets between all years, the starting dates for cumulative time series (Figs. 7 and 8) were set to 1 May. For time series that started later in the season, we used the available budget from the nearest year (either prior to or after the year of observation). Accordingly, not all displayed time series start with a value of zero, and final values therefore do not always represent the cumulative budget based on the available observations. This approach facilitates a qualitative comparison of seasonal trends in $\mathrm{CO}_{2}$ exchange between different data years, while absolute numbers of the seasonal budgets are subject to significant uncertainty for years with data gaps.

The observed differences in cumulative uptake for the historic dataset reflect the interannual variability in $\mathrm{CO}_{2}$ fluxes that can be expected in this type of ecosystem (Fig. 7a, 20022004). Such changes are primarily caused by varying climate conditions from year to year (Merbold et al., 2009). In contrast, 2005 - the year immediately following the installation of the drainage system - shows a systematic dampening in the seasonal course of net carbon exchange (Fig. 7b), even though the cumulative NEE budget at the end of the growing season is comparable to previous years' levels.

A direct comparison of the recent and historic carbon flux patterns in Fig. 7 shows that the seasonal amplitude of the cumulative $\mathrm{CO}_{2}$ budget has increased over the past decade. Maximum $\mathrm{CO}_{2}$ uptake rates are higher at peak growing season in July, and initial carbon release immediately following snowmelt ( $\sim$ May-June) seems to have increased as well. In contrast, net $\mathrm{CO}_{2}$ emission rates in autumn appear to be similar between recent and historic datasets. As a consequence, the average cumulative growing season uptake of $\mathrm{CO}_{2}$ by the ecosystem has grown over the past $\sim 10$ years.

While the range of the cumulative $\mathrm{CO}_{2}$ budget has partial overlap between the recent and historic data years for control conditions, the fluxes observed immediately after the disturbance (2005) and recent fluxes from the drained area display systematic differences, both in absolute values as well as in seasonal patterns. This finding suggests that the disturbed area may have rebounded from the immediate drainage effects and the resulting dampened seasonality that occurred shortly after the disturbance. Instead, recent $\mathrm{CO}_{2}$ uptake rates from the drained section of the tundra partly exceed the rates observed for the control area before installation of the drainage (Fig. 7, 2002-2004).

The seasonal $\mathrm{CO}_{2}$ exchange for the overlapping data period (19 July to 23 September) for the years 2002-2004 summed up to $-42,-21$, and $-16 \mathrm{gCO}_{2} \mathrm{Cm}^{-2}$, respectively, and $-46,-63$, and $-41 \mathrm{gCO}_{2} \mathrm{C} \mathrm{m}^{-2}$, respectively, for the years 2013-2015 under control conditions. For the drained part of the tundra, we found $-10 \mathrm{gCO}_{2}-\mathrm{C} \mathrm{m}^{-2}$ for 2005 and $-20,-48$, and $-12 \mathrm{gCO}_{2}-\mathrm{C} \mathrm{m}^{-2}$ for 2013-2015, respectively. Negative budgets over most of the growing season in all observation years indicate that both the drained and control ecosystems act as net sinks for atmospheric $\mathrm{CO}_{2}$ during this part of the year. However, the drained ecosystem displays slightly different exchange patterns for $\mathrm{CO}_{2}$, with higher respiration rates throughout the growing season, making it a weaker $\mathrm{CO}_{2}$ sink in comparison to the control site.

Separation of NEE into its individual component fluxes GPP and $R_{\text {eco }}$ - demonstrates that the interannual variability in both cumulative time series (recent: 2013-2015; historic: 2002-2005) increased strongly after mid-July. Net flux variability is dominated by changes in photosynthetic uptake (Fig. 8b). Absolute cumulative flux rates of GPP and $R_{\text {eco }}$ tend to be higher at the drained site, indicating that the carbon turnover rates have increased as a consequence of drainage. The long-term tendencies toward higher net $\mathrm{CO}_{2}$ uptake of the ecosystem during the summer are mainly driven by in- 
creases in GPP since overall increases in photosynthetic uptake outweigh higher respiration losses.

\subsection{Linking interannual shifts in carbon fluxes to phenology}

We found a strong interannual variability in timing for key phenological stages in the Chersky area (for the MODIS period, 2000 to present) with respect to the start (SOS), peak (POS), and end (EOS) of the season (Fig. 3). Maximum year-to-year variability ranged between 18,26 , and 6 days for SOS, POS, and EOS, respectively. Focusing exclusively on the observation periods 2002-2005 and 2013-2015, we found a maximum difference of 18 days between the shortest (118 days, in 2015) and longest (136 days, in 2005) growing season lengths. Neither the timing nor duration of seasons showed any long-term trends, resulting in no detected systematic differences in phenology between the historic and recent observation periods.

Our limited data availability precludes establishing significant links between phenology and NEE data. The analysis of the interannual variability of cumulative $\mathrm{CO}_{2}$ flux budgets was executed only for the control site, limiting the data pool to just 6 years (2002-2004 and 2013-2015). Moreover, observations made during the historic period did not cover the entire growing season in some years, further reducing the database for the purpose of statistical analyses. It was therefore not possible to identify meaningful links between individual key dates and NEE patterns. Similarly, no direct correlation between growing season length and NEE budgets in either the recent or historic datasets was found.

Normalizing $\mathrm{CO}_{2}$ time series to account for shifts in phenology (see Fig. 3 and Sect. 2.6) removes interannual variability in cumulative flux budgets and separates the cumulative $\mathrm{CO}_{2}$ budgets into two distinct groups, the recent (20132015) and the historic (2002-2004) datasets (Fig. 9). Differences in $\mathrm{CO}_{2}$ flux budgets become particularly obvious in the early and late seasons (Fig. 9b and c). A linear regression fit to identify the maximum gradient of the growing season $\mathrm{CO}_{2}$ uptake (Table 2) confirms this separation, indicating a significant increase in this peak NEE uptake (ANOVA, $p<0.05)$ between historic and recent datasets. However, the timing of the maximum uptake (as DOY of maximum gradient, Table 2) seems not to be influenced, as dates vary from mid- to late July without any clear pattern. For this gradient analysis we tested different sizes of the moving window, and found no sensitivity of the obtained results towards this parameter. During both the pre- and post-season the net $\mathrm{CO}_{2}$ release signal shows only minor differences between the recent and historic data (Fig. 9a and d).
Table 2. Results from the linear regression of cumulative $\mathrm{CO}_{2}$ fluxes during the growing season with day of year (DOY) of maximum gradient and maximum gradient slope.

\begin{tabular}{ccc}
\hline Year & $\begin{array}{c}\text { DOY of } \\
\text { maximum uptake }\end{array}$ & $\begin{array}{r}\text { Maximum } \\
\text { gradient }\end{array}$ \\
\hline 2002 & 204 & -0.050 \\
2003 & 195 & -0.044 \\
2004 & 203 & -0.039 \\
2013 & 210 & -0.060 \\
2014 & 195 & -0.061 \\
2015 & 191 & -0.063 \\
\hline
\end{tabular}

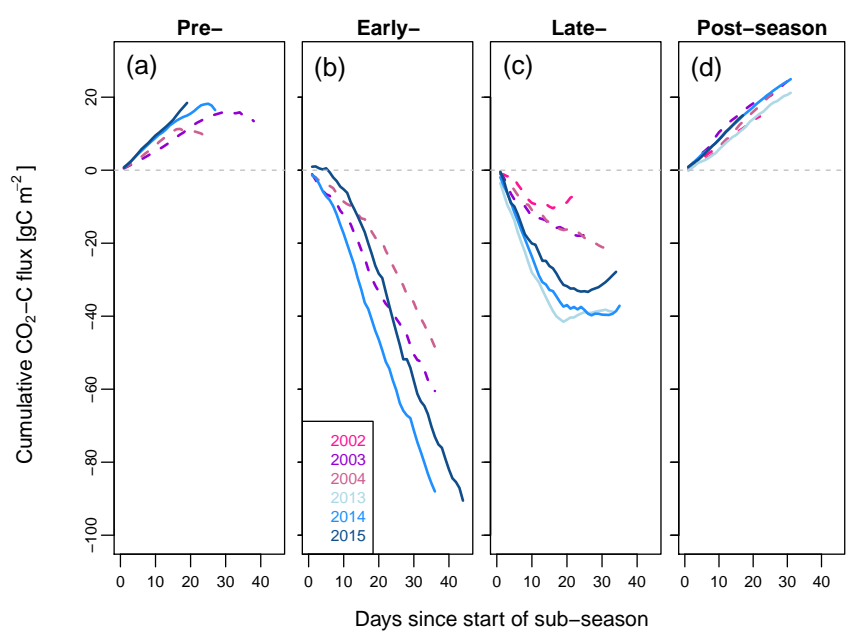

Figure 9. Sub-seasonal $\mathrm{CO}_{2}$ flux budgets for the control area for the historic (2002-2004) and recent (2013-2015) datasets. Time axes within this plotting scheme are identical to those used in Fig. 5.

\section{Discussion}

\subsection{Impact of decadal drainage}

In Arctic tundra ecosystems reduced soil moisture and the related decrease in water table depth increase the decomposition of soil carbon. This stems from the increased diffusion of oxygen into the soil (Billings et al., 1982; Oechel et al., 1998; Peterson et al., 1984), which induces higher $\mathrm{CO}_{2} \mathrm{ex}-$ change fluxes to the atmosphere. In contrast, partitioning of the NEE signal indicates a minor increase in GPP rates at the drained site, which can be attributed to a shift in the vegetation composition. Drainage has led to the establishment of more tussock-forming sedges (Carex species) and shrubs (Betula exilis and Salix species), while the undisturbed parts of this tundra ecosystem are instead dominated by cotton grasses (Eriophorum angustifolium, Kwon et al., 2016). Such shifts in vegetation community structure have been associated with differing $\mathrm{CO}_{2}$ uptake patterns (Christensen et al., 2000). Major differences - which were especially clear in the early and late season, when emissions from the drained 
site exceeded those found at the control site - are caused by higher respiration activity, triggered by higher soil temperatures (Kwon et al., 2016; see also Fig. A1c and d) in the upper part of the active layer (Lloyd and Taylor, 1994).

In an earlier study, Merbold et al. (2009) could not show a significant change in the $\mathrm{CO}_{2}$ exchange patterns immediately following this drainage disturbance. As this result can be attributed to the shorter observation period of only a single data year, neither long-term effects nor interannual variability could be taken into account. In contrast, in the present study we demonstrate that long-term ( $>10$ years) drainage had a significant impact on the carbon cycle processes of this tundra ecosystem. Since recent $\mathrm{CO}_{2}$ uptake rates from the drained site at times exceed the rates observed for the control area before installation of the drainage, we conclude that the drained section has largely adapted to the new conditions, with features such as vegetation and microbial community structures that can tolerate lower average water table depths and stronger fluctuations in water availability over the course of the growing season (Kwon et al., 2016). Concerning interannual variability in the fluxes, ecosystem respiration seems to be relatively unaffected by annual shifts in either climate or water conditions, while assimilation can vary substantially from year to year. This variability in GPP is primarily due to changing temperatures and cloud cover and is further amplified under the influence of fluctuating water regimes at the drained site. Finally, despite the fact that long-term changes in site conditions (e.g., water availability, plant communities) can lead to systematic shifts in both absolute fluxes and flux components, we found interannual variability to remain at approximately the same level between historic and recent data.

To our knowledge, our study represents the only longterm experiment focusing on the net impact of lowered water table depths on summertime $\mathrm{CO}_{2}$ fluxes in Arctic tundra ecosystems. Existing water manipulation approaches have been conducted that can be used to evaluate our findings despite the fact that differences between wet and dry sites were obtained by wetting the natural tundra instead of drying as in case of the presented study. For example, in one study, longterm water table depth increase triggered a stronger $\mathrm{CO}_{2}$ sink during the growing season by promoting photosynthetic uptake during the summer (Lupascu et al., 2014). Other studies found lower $\mathrm{CO}_{2}$ emissions during autumn as a consequence of wetter conditions (Christiansen et al., 2012). Similar conclusions were drawn in the present study, where wetter conditions under undisturbed conditions led to lower respiration rates and a higher $\mathrm{CO}_{2}$ sink compared to the drained site. However, a direct comparison of our results with prior studies is compromised due to the different measurement techniques used, as well as the multi-factorial interaction of different treatments combined with the increased water table depth.

Similar findings to these long-term experiments have been described by studies that focus on short-term processes using an eddy-covariance method. Dry conditions are considered to be an important control factor for the terrestrial carbon cycle and have been linked to increased respiration rates during the growing seasons (Aurela et al., 2007; Huemmrich et al., 2010; Lund et al., 2012; Zona et al., 2010). Such findings are in line with the results we obtained shortly after the setup of the drainage channel (2005). Although Zimov et al. (1996) observed the highest effluxes during the wettest year in an area close to our site, these results may have been influenced by small-scale heterogeneity and differences in measurement technique (i.e., chamber vs. eddy covariance).

\subsection{Seasonal development and interannual variability of $\mathrm{CO}_{2}$ fluxes}

The methods and limits used in determining the key dates for seasonality have a high degree of uncertainty. This uncertainty can influence the key dates derived to indicate SOS, POS, and EOS, which can in turn lead to uncertainty in the growing season and sub-seasonal NEE budgets. Variable spring flooding can also affect the duration of the growing season through an indirect shift in key dates and can reduce $\mathrm{CO}_{2}$ uptake during the growing season (Zona et al., 2012). However, as we do not expect potential uncertainties in the key dates to cause systematic shifts in seasonal trends and budgets, the qualitative results presented in the present study should not be affected.

Here, we compare two observation periods, the historic (2002-2005) and the recent dataset (2013-2015), both covering 3 years of control measurements. These time frames might not be sufficient to fully represent conditions within each observation period, since surface-atmosphere exchange processes are often subject to pronounced interannual variability. Long-term continuous observations would allow a more in-depth statistical analysis. However, we observed characteristic patterns (e.g., the maximum $\mathrm{CO}_{2}$ uptake rate in summer) that clearly showed a distinctive trend between historic and recent periods. Thus, even from this limited database, we can see that the ecosystem has undergone a systematic shift over the past $\sim 12$ years.

Pronounced net $\mathrm{CO}_{2}$ emissions to the atmosphere at the start of the growing season, as observed in this study during the pre-season, have previously been described by other studies for Arctic tundra sites (Corradi et al., 2005; Euskirchen et al., 2012; Grøndahl et al., 2007; Kutzbach et al., 2007; Nordstroem et al., 2001; Oechel et al., 1997, 2014; Parmentier et al., 2011; van der Molen et al., 2007; Zimov et al., 1996). During the pre-season, respiration clearly dominates the $\mathrm{CO}_{2}$ flux signal, while the onset of photosynthetic uptake is delayed even though environmental conditions are adequate (e.g., mean temperature $=8.1{ }^{\circ} \mathrm{C}$, mean shortwave incoming radiation $=170 \mathrm{~W} \mathrm{~m}^{-2}$ ). This observation, which differs markedly from the results of other studies focusing on Arctic tundra $\mathrm{CO}_{2}$ flux exchange (Harazono et al., 2003; Kutzbach et al., 2007), might be associated with the very low 
abundance of mosses in this specific ecosystem (Kwon et al., 2016).

The interannual variability of cumulative $\mathrm{CO}_{2}$ fluxes is weak during the pre-season, even if environmental conditions (i.e., air and soil temperatures, soil moisture) are highly diverse both within and before the individual pre-seasons. For example, 2004 showed exceptionally high air temperatures during this sub-season, while net $\mathrm{CO}_{2}$ emissions remained at the same levels as had been observed for years with more regular temperature courses (Fig. B2 in Appendix B). In contrast, in 2015 release rates were higher than average during a relatively cold pre-season. We were unable to correlate the early start of the growing season and warm springtime conditions with increased uptake patterns during the growing season as described by other studies such as Aurela et al. (2004) and Euskirchen et al. (2012). These findings suggest that, for our study site near Chersky, early-season emissions may be affected by both conditions during winter (i.e., snow cover and depth, onset of snowmelt) and transition period (i.e., start and intensity of the flooding event). A detailed effect cannot be quantified here since all relevant snow regime dynamics happen before the start of the pre-season. Based on the available data, no direct correlation between the years with the lowest uptake over the growing season and the strongest flooding event were observed; an isolated effect of the flooding event therefore cannot explain the observed interannual variability.

Both peak uptake rates and the timing of these peaks at the end of the early season (i.e., mid- to late July) agree with findings presented for tundra systems across the Arctic circle (Euskirchen et al., 2012; Grøndahl et al., 2007; Harazono et al., 2003; Kutzbach et al., 2007; Lafleur and Humphreys, 2007; Nordstroem et al., 2001; Oechel et al., 2014). During the late season the shift of the balance between respiration and assimilation towards a net release of $\mathrm{CO}_{2}$ is highly variable between years. Results from 2014 indicate that the length of the net uptake season is highly sensitive towards climate conditions in July to August. In 2014, warm temperatures $\left(>5^{\circ} \mathrm{C}\right.$ compared to the average monthly mean in August) led to an increased net $\mathrm{CO}_{2}$ uptake from mid-July to the end of October by $\sim 20 \mathrm{gCO}_{2}-\mathrm{C} \mathrm{m}^{-2}$.

The year-to-year variability in NEE during the early and late seasons is dominated by variability in GPP (Euskirchen et al., 2012; van der Molen et al., 2007). In our study, we found GPP also to be the main driver of shifts in summertime $\mathrm{CO}_{2}$ fluxes between the recent and historic datasets. The observed net increase in the $\mathrm{CO}_{2}$ sink strength in recent years can be attributed to significant increases in $\mathrm{CO}_{2}$ uptake rates around the peak of the growing season (Table 2). This observed separation in the cumulative $\mathrm{CO}_{2}$ patterns (Fig. 9) between historic and recent periods cannot be attributed to systematic changes in climate: There are no systematic trends in air temperatures over the last decade in the Chersky region, and, particularly during the early and late season, average conditions were found to be very sta- ble over the years (Fig. B1). Small deviations in temperature during pre- and post-seasons are not correlated with the observed trends in $\mathrm{CO}_{2}$ uptake. However, we observed a minor increase in cumulative NDVI values (Fig. B2) in recent years (2013-2015), and these higher photosynthetic leaf areas might indicate an overall increase in light use efficiency within this ecosystem. Since the MODIS NDVI data result from a mixed product covering both the control and drained sites, values might have changed slightly due to changes in the vegetation composition at the drained site (Kwon et al., 2016). However, considering these small differences without a trend between recent and historic years, this data product alone cannot provide a final answer regarding overall shifts in vegetation structure.

Another possible factor influencing the differences observed between recent and historic datasets is the location of the control site. Since the control site from the historic dataset was converted into a drained site in autumn 2004 with the installation of the drainage ditch, a new control site had to be chosen for the recent measurements. Elevation measurements in 2014 indicated that parts of the drained site are slightly lower than the surrounding terrain (up to $\sim 0.5 \mathrm{~m}$ ). Within the floodplain environment, such minor topographic depressions preferentially collect melt and flood water; accordingly, control observations made during the historic period may have been subject to more pronounced flooding as compared to the recent control observations at the new tower position. More standing water surrounding the tower site could in turn cause differences in photosynthetic activity, respiration rates, and NDVI. Flooding dynamics can also influence carbon exchange fluxes and increase $\mathrm{CO}_{2}$ losses (Zona et al., 2012). However, differences in elevation might have been less pronounced in the historic dataset, since subsidence may have been a secondary disturbance effect triggered by the lowered water table depth in this area.

Similar year-to-year patterns of pronounced $\mathrm{CO}_{2}$ efflux rates can be observed in the post-season, where temperatures remain above freezing in most soil layers with favorable conditions for the microbial decomposition, triggering enhanced $\mathrm{CO}_{2}$ emissions (Parmentier et al., 2011). However, unlike Oechel et al. (2014), respiration rates at our site are lower during post-season $(\sim 35 \%)$ than during late season. This is primarily due to biogeophysical differences in the site conditions in Chersky as compared to the Alaska North Slope sites near Barrow. While thawing of the active layer continues in autumn near Atqasuk (Alaska, US), soil temperatures are already starting to decrease by August to September (see Fig. A1c and Table A1) in Chersky.

\section{Conclusions}

Our results demonstrate that a long-term drainage experiment ( $>10$ years) in a permafrost floodplain in northeastern Siberia has significant effects on growing season $\mathrm{CO}_{2}$ 
exchange patterns in comparison to a control site reflecting undisturbed conditions.

\subsection{Drainage effect on recent $\mathrm{CO}_{2}$ fluxes}

Our observations show that the net $\mathrm{CO}_{2}$ sink strength of the drained ecosystem was reduced by $20-40 \mathrm{gCO}_{2}-\mathrm{C} \mathrm{m}^{-2}$ per year over the three observed growing seasons (2013-2015). Differences in NEE between the drained and control ecosystems are dominated by increased respiration rates at the drained site, primarily triggered by higher near-surface temperatures. In contrast, we found only minor effects on photosynthetic uptake, and the differences between the drained and control sites were less systematic across data years. Still, both ecosystems show negative flux budgets over the growing seasons, representing a net sink of $\mathrm{CO}_{2}$ from the atmosphere.

\subsection{Longer-term trends in $\mathrm{CO}_{2}$ budgets}

The comparison of recent flux data to historic conditions (2002-2005) indicates that this tundra ecosystem is now a stronger sink for $\mathrm{CO}_{2}$ over the summer months than it was about 10 years ago. This finding can be linked to an increase in seasonality, with higher net emissions after the snowmelt, as well as to strongly intensified uptake rates at the peak of the growing season in July. The observed long-term shifts are dominated by higher photosynthetic uptake and a resulting stronger carbon sink capacity for $\mathrm{CO}_{2}$ over the whole growing season, most likely linked to a trend towards higher plant biomass.

\subsection{Ecosystem adaptation following disturbance}

Our results demonstrate that the drained ecosystem did recover from the intermediate disturbance impact in 2005 (directly after the installation of the drainage), when net carbon exchange rates showed a systematically damped seasonal course. $\mathrm{CO}_{2}$ flux data from recent years indicate that the drained ecosystem has adapted to the disturbance, with changes in the biotic and abiotic conditions leading to a rebound to previous carbon flux levels.

\subsection{Seasonality in summertime $\mathrm{CO}_{2}$ exchange processes}

Concerning recent effects of the drainage disturbance, $70 \%$ of the observed differences in cumulative $\mathrm{CO}_{2}$ budgets can be attributed to conditions in the high-summer period (JulyAugust), when the effect of reduced water availability is most pronounced. Concerning long-term trends, the major part of the differences between historic and recent flux budgets was found in the early season, when the long-term increasing trend in photosynthetic uptake has the strongest effect. 


\section{Appendix A: Recent environmental conditions (2013-2015)}

Large differences in all meteorological site conditions were found for all sub-seasons and over the entire year (Table A1). For example, in 2014 the mean annual temperature was $-10^{\circ} \mathrm{C}$, with daily means ranging from $-49^{\circ} \mathrm{C}$ in January to $+22^{\circ} \mathrm{C}$ in July. Early and late seasons are the warmest periods of the year for both air and soil temperatures, with particularly high values observed during late season 2014. Long-term air temperature averages (Rohde et al., 2013) for August 1982-2011 (data not shown here) indicate conditions above the monthly mean for 2014 and below the monthly mean for 2013 and 2015.

A pronounced seasonal cycle due to freezing-thawing dynamics is observed in the soil temperatures (Fig. A1c). For both sites, the active layer was completely frozen until early June, with thawing gradually beginning from the top down. During the growing season the active layer increases up to a depth of $\sim 0.4-0.5 \mathrm{~m}$ (data not shown). Refreezing usually starts at end of September and proceeds both from the surface downwards and permafrost upwards. For both the frozen and unfrozen conditions the drained site had higher soil temperatures (Fig. A1c). The largest differences during the growing season occurred during July and August with a $\sim 2.5^{\circ} \mathrm{C}$ higher soil temperature at the drained site.

While precipitation is variable throughout the year, over $80 \%$ of the annual budget was collected during the growing season in our datasets for 2014 and 2015. Rain events are strongest during early and late season (Table A1 and Fig. A2b) with events ranging from 0.1 to $16 \mathrm{~mm} \mathrm{~d}^{-1}$. These events have a direct influence on soil moisture (Fig. A2b). After flooding abates soil moisture drops rapidly, especially in the tussocks (data not shown). During rain events the soil moisture can increase to maximum values, depending on the intensity of the rain event. Soil moisture values are lower at the drained site than under natural conditions; this can be explained by the $\sim 0.2 \mathrm{~m}$ difference in water table depth (over and under the soil surface for control and drained ecosystems, respectively) between treatments (Kwon et al., 2016). While values for both 2013 and 2015 (Fig. A1b) indicated very dry conditions under disturbed conditions, saturation during late season 2014 (data not shown) at both towers had the same value (soil water content at $0.08 \mathrm{~m}$ depth).
Net radiation is dominated by strong changes in the albedo and pronounced differences in shortwave radiation. Shortwave radiation varies enormously, with $24 \mathrm{~h}$ during polar summer, none during polar winter, and transition periods between. Levels of net radiation during the overlapping period of 2013-2015 (see Table A1) are comparable. Pre-season data indicate that the highest net radiation values trigger plant growth and that the rapidly decreasing radiation that occurs during late season fuels an already early senescence of the vegetation. 
Table A1. Environmental conditions measured at Tower 1 (drained): air temperature $\left(T_{\mathrm{a}}\right)$ at a $2 \mathrm{~m}$ height, soil temperature $\left(T_{\mathrm{S}}\right)$ at a $0.8 \mathrm{~m}$ depth and net radiation $\left(R_{\mathrm{n}}\right)$. Values are given as mean $( \pm \mathrm{SD})$, with the exception of precipitation (PPT, sum per season). Measurements from 2013 started mid-July (late season); no data are therefore available before this time. The growing season is divided into sub-seasons; [length of season] is the total number of days.

\begin{tabular}{llrrrr}
\hline Year & Season & $\begin{array}{r}T_{\mathrm{a}} \\
\left({ }^{\circ} \mathrm{C}\right)\end{array}$ & $\begin{array}{r}T_{\mathrm{S}} \\
\left({ }^{\circ} \mathrm{C}\right)\end{array}$ & $\begin{array}{r}R_{\mathrm{n}} \\
\left(\mathrm{W} \mathrm{m}^{-2}\right)\end{array}$ & $\begin{array}{r}\mathrm{PPT} \\
(\mathrm{mm})\end{array}$ \\
\hline \multirow{2}{2}{2013} & Late season [33] & $8.7(5.4)$ & $3.8(1.1)$ & $80(120)$ & NA \\
& Post-season [31] & $1.8(4.8)$ & $0.9(0.7)$ & $29(82)$ & NA \\
\hline \multirow{2}{*}{2014} & Year & $-10.1(18.9)$ & $-2.8(6.4)$ & $32(103)$ & 173 \\
& Growing season [129] & $9.5(7.4)$ & $3.8(2.7)$ & $89(137)$ & 153 \\
& Pre-season [27] & $8.6(6.1)$ & $1.9(1.7)$ & $143(166)$ & 28 \\
& Early season [36] & $14(6.4)$ & $6.1(1.5)$ & $121(142)$ & 41 \\
& Late season [35] & $12.1(6.3)$ & $5.3(1.8)$ & $80(125)$ & 74 \\
& Post-season [31] & $2.2(3.9)$ & $0.8(0.9)$ & $19(75)$ & 10 \\
\hline \multirow{2}{2015}{ Year } & $-11.3(18.7)$ & $-2.4(5.0)$ & $28(96)$ & 118 \\
& Growing season [114] & $10.1(6.8)$ & $3.3(2.2)$ & $101(141)$ & 99 \\
& Pre-season [19] & $8.1(5.8)$ & $0.3(0.9)$ & $148(170)$ & 13 \\
& Early season [44] & $14.9(6.1)$ & $5.2(1.5)$ & $126(148)$ & 48 \\
& Late season [34] & $7.7(4.7)$ & $3.6(1.1)$ & $72(113)$ & 32 \\
& Post-season [17] & $4.9(5.2)$ & $1.4(0.7)$ & $39(90)$ & 6 \\
\hline
\end{tabular}

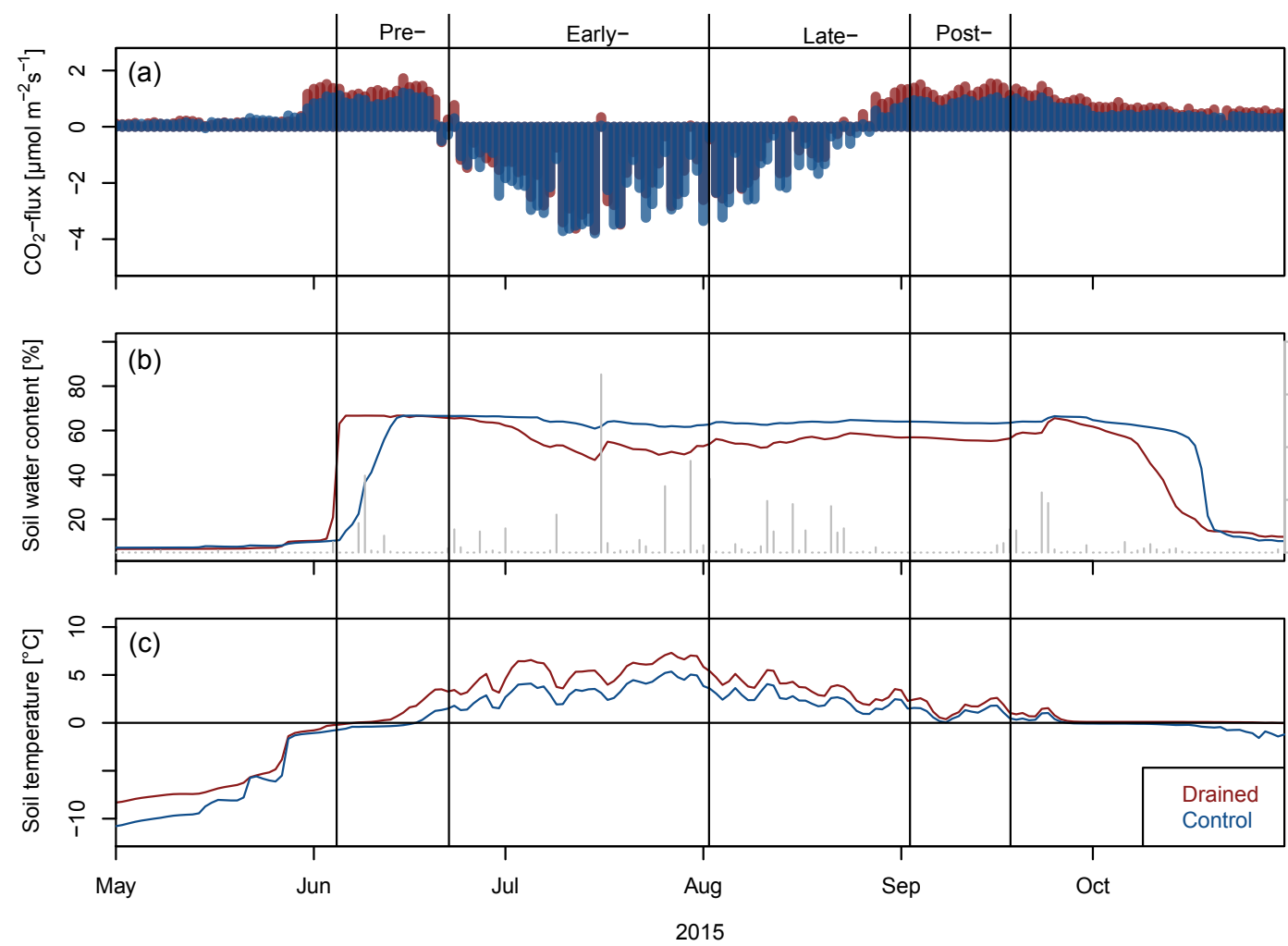

Figure A1. Daily mean (a) carbon fluxes, (b) soil water content at $0.08 \mathrm{~m}$ depth, and (c) soil temperature at $0.08 \mathrm{~m}$ depth. Since precipitation patterns are very similar between sites, only data from the drained site are displayed. Vertical lines divide the 2015 growing season into sub-seasons. 


\section{Appendix B: Long-term environmental conditions}

Variability in cumulative air temperature was observed, especially during pre- and post-season, while early and late seasons showed more uniform patterns. The most notable findings were the warm conditions during the 2004 pre-season, which, combined with a short sub-season, indicates a relatively early and intense start to the growing season. The same values in at the end of the 2003 pre-season are attributed to a remarkably long sub-season. During the early and late season, air temperature developed very similarly in all observed years, with different data years marking the minimum and maximum thresholds. Extreme warm conditions are again observed in the 2002 and 2003 post-seasons, with values twice as high as for the remaining years in the dataset.

A subtle trend was observed in cumulative NDVI values (Fig. B2), with recent years at the upper range of the values observed for the historic period. At the same time, all data years show very similar patterns within each sub-season, with differences in values mainly attributable to the individual length of specific sub-seasons.

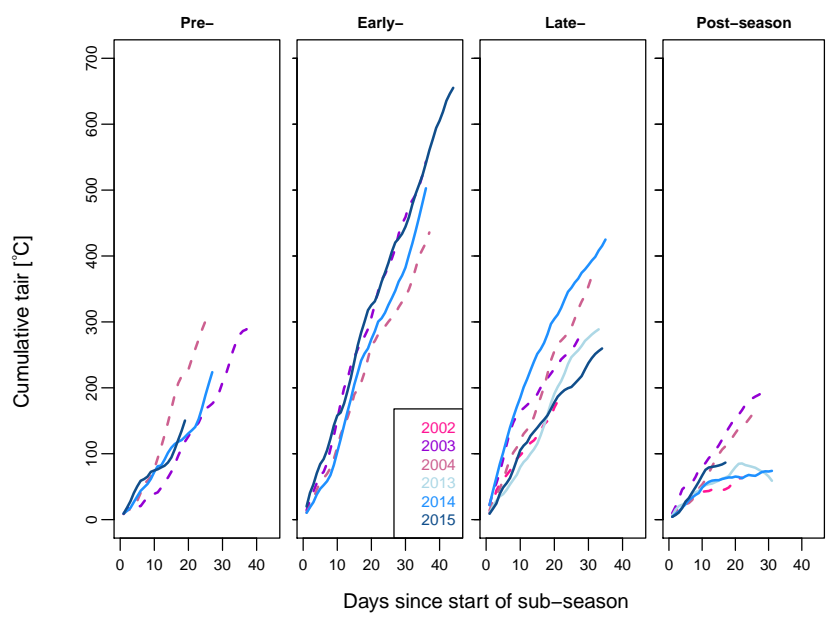

Figure B1. Sub-seasonal air temperature (at a $6 \mathrm{~m}$ height) budgets for the control area for the historic (2002-2004) and recent (20132015) datasets. Time axes within this plotting scheme are identical to those used in Fig. 5.

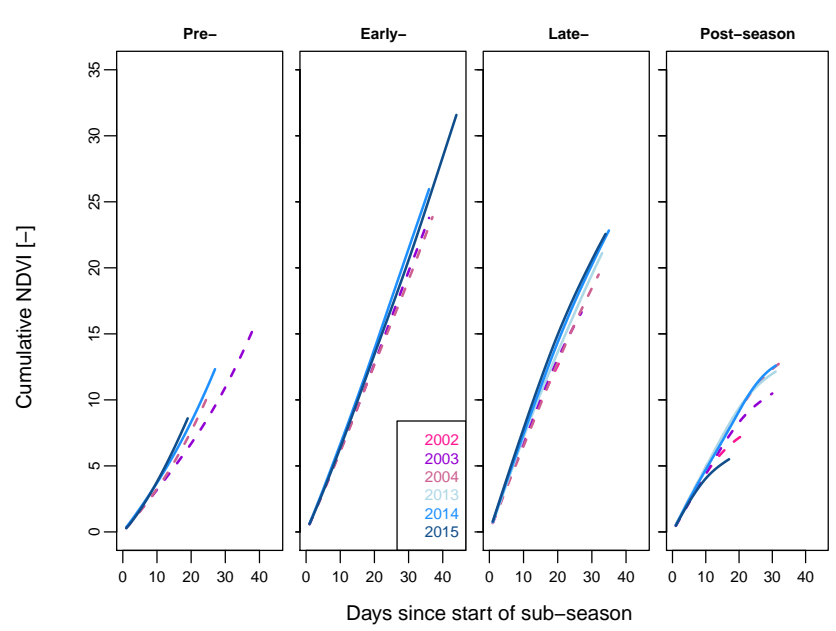

Figure B2. Sub-seasonal NDVI budgets for the control area for the historic (2002-2004) and recent (2013-2015) datasets. Time axes within this plotting scheme are identical to those used in Fig. 5. 


\section{The Supplement related to this article is available online at doi:10.5194/bg-13-5315-2016-supplement.}

Author contributions. We applied first-last-author emphasis and equal-contribution (alphabetical sequence) methods for the order of authors (Tscharntke et al., 2007).

Acknowledgements. This work was supported by the European Commission (PAGE21 project, FP7-ENV-2011, grant agreement no. 282700; and PerCCOM project, FP7-PEOPLE-2012-CIG, grant agreement no. PCIG12-GA-201-333796), the German Ministry of Education and Research (CarboPerm-Project, BMBF grant no. 03G0836G), the AXA Research Fund (PDOC_ 2012_W2 campaign, ARF fellowship M. Göckede), and the European Science Foundation (ESF for the activity "Tall Tower and Surface Research Network for Verification of Climate Relevant Emissions of Human Origin", Short Visit Grant, fellowship F. Kittler). The authors appreciate the efforts of NESS staff members, especially Galina Zimova and Nastya Zimova, for organizing field work; they also recognize the team from the Field Experiments \& Instrumentation group (MPI-BGC), especially Martin Hertel, for supporting field work. We thank Thomas Foken and Werner Eugster for scientific input and discussion.

The article processing charges for this open-access publication were covered by the Max Planck Society.

Edited by: I. Laurion

Reviewed by: two anonymous referees

\section{References}

ACIA: Impacts of a Warming Arctic: Arctic Climate Impacts Assessment, Cambridge, 2004.

Aurela, M., Laurila, T., and Tuovinen, J.-P.: The timing of snow melt controls the annual $\mathrm{CO}_{2}$ balance in a subarctic fen, Geophys. Res. Lett., 31, 826-837, 2004.

Aurela, M., Riutta, T., Laurila, T., Tuovinen, J.-P., Vesala, T., Tuittila, E. S., Rinne, J., Haapanala, S., and Laine, J.: $\mathrm{CO}_{2}$ exchange of a sedge fen in southern Finland - the impact of a drought period, Tellus B, 59, 826-837, 2007.

Beer, C.: Soil science - The Arctic carbon count, Nat. Geosci., 1, 569-570, 2008.

Billings, W. D., Luken, J. O., Mortensen, D. A., and Peterson, K. M.: Arctic Tundra - a Source or Sink for Atmospheric CarbonDioxide in a Changing Environment, Oecologia, 53, 7-11, 1982.

Bret-Harte, M. S., Mack, M. C., Shaver, G. R., Huebner, D. C., Johnston, M., Mojica, C. A., Pizano, C., and Reiskind, J. A.: The response of Arctic vegetation and soils following an unusually severe tundra fire, Philos. T. R. Soc. B, 368, doi:10.1890/ES1100202.1, 2013.

Burba, G. G., Anderson, D. J., Xu, L., and K., M. D.: Correcting apparent off-season $\mathrm{CO}_{2}$ uptake due to surface heating of a an open path gas analyzer: process report of an ongoing study, 27th Conference on Agricultural and Forest meteorology, San Diego, CA, 13 pp., 2006.

Burba, G. G., McDermitt, D. K., Grelle, A., Anderson, D. J., and $\mathrm{Xu}, \mathrm{L} .:$ Addressing the influence of instrument surface heat exchange on the measurements of $\mathrm{CO}_{2}$ flux from open-path gas analyzers, Glob. Change Biol., 14, 1854-1876, 2008.

Christensen, T. R., Friborg, T., Sommerkorn, M., Kaplan, J., Illeris, L., Soegaard, H., Nordstroem, C., and Jonasson, S.: Trace gas exchange in a high-Arctic valley: 1 . Variations in $\mathrm{CO}_{2}$ and $\mathrm{CH}_{4}$ Flux between tundra vegetation types, Global Biogeochem. Cy., 14, 701-7013, 2000.

Christiansen, C. T., Svendsen, S. H., Schmidt, N. M., and Michelsen, A.: High arctic heath soil respiration and biogeochemical dynamics during summer and autumn freeze-in - effects of long-term enhanced water and nutrient supply, Glob. Change Biol., 18, 3224-3236, 2012.

Corradi, C., Kolle, O., Walter, K., Zimov, S. A., and Schulze, E. D.: Carbon dioxide and methane exchange of a north-east Siberian tussock tundra, Glob. Change Biol., 11, 1910-1925, 2005.

Curry, J. A., Schramm, J. L., and Ebert, E. E.: Sea-Ice Albedo Climate Feedback Mechanism, J. Climate, 8, 240-247, 1995.

Euskirchen, E. S., Bret-Harte, M. S., Scott, G. J., Edgar, C., and Shaver, G. R.: Seasonal patterns of carbon dioxide and water fluxes in three representative tundra ecosystems in northern Alaska, Ecosphere, 3, G00i02, doi:10.1029/2009jg001237, 2012.

Flanagan, L. B. and Syed, K. H.: Stimulation of both photosynthesis and respiration in response to warmer and drier conditions in a boreal peatland ecosystem, Glob. Change Biol., 17, 2271-2287, 2011.

Foken, T. and Mauder, M.: Eddy-Covariance Software TK3, doi:10.5281/zenodo.20349, 2015.

Foken, T. and Wichura, B.: Tools for quality assessment of surfacebased flux measurements, Agr. Forest Meteorol., 78, 83-105, 1996.

Forkel, M., Carvalhais, N., Verbesselt, J., Mahecha, M. D., Neigh, C. S. R., and Reichstein, M.: Trend Change Detection in NDVI Time Series: Effects of Inter-Annual Variability and Methodology, Remote Sens.-Basel, 5, 2113-2144, 2013.

Grøndahl, L., Friborg, T., and Soegaard, H.: Temperature and snowmelt controls on interannual variability in carbon exchange in the high Arctic, Theor. Appl. Climatol., 88, 111-125, 2007.

Harazono, Y., Mano, M., Miyata, A., Zulueta, R. C., and Oechel, W. C.: Inter-annual carbon dioxide uptake of a wet sedge tundra ecosystem in the Arctic, Tellus B, 55, 215-231, 2003.

Huemmrich, K. F., Kinoshita, G., Gamon, J. A., Houston, S., Kwon, H., and Oechel, W. C.: Tundra carbon balance under varying temperature and moisture regimes, J. Geophys. Res.-Biogeo., 115, G00i02, doi:10.1029/2009jg001237, 2010.

Hugelius, G., Strauss, J., Zubrzycki, S., Harden, J. W., Schuur, E. A. G., Ping, C.-L., Schirrmeister, L., Grosse, G., Michaelson, G. J., Koven, C. D., O’Donnell, J. A., Elberling, B., Mishra, U., Camill, P., Yu, Z., Palmtag, J., and Kuhry, P.: Estimated stocks of circumpolar permafrost carbon with quantified uncertainty ranges and identified data gaps, Biogeosciences, 11, 6573-6593, doi:10.5194/bg-11-6573-2014, 2014.

IPCC: Climate Change 2013: The Physical Science Basis, Contribution of Working Group I to the Fifth Assessment Report of the Intergovernmental Panel on Climate Change, Cambridge Uni- 
versity Press, Cambridge, United Kingdom and New York, NY, USA, 2013

Jorgenson, M. T., Shur, Y. L., and Pullman, E. R.: Abrupt increase in permafrost degradation in Arctic Alaska, Geophys. Res. Lett., 33, L02503, doi:10.1029/2005g1024960, 2006.

Kaufman, D. S., Schneider, D. P., McKay, N. P., Ammann, C. M., Bradley, R. S., Briffa, K. R., Miller, G. H., Otto-Bliesner, B. L., Overpeck, J. T., Vinther, B. M., and Arctic Lakes 2k Project, M.: Recent warming reverses long-term arctic cooling, Science, 325, 1236-1239, 2009.

Kirschbaum, M. U. F.: The Temperature-Dependence of Soil Organic-Matter Decomposition, and the Effect of Global Warming on Soil Organic-C Storage, Soil Biol. Biochem., 27, 753760, 1995

Kolle, O. and Rebmann, C.: EddySoft; Documentation of a Software Package to Acquire and Process Eddy Covariance Data, Jena, 2007.

Koven, C. D., Ringeval, B., Friedlingstein, P., Ciais, P., Cadule, P., Khvorostyanov, D., Krinner, G., and Tarnocai, C.: Permafrost carbon-climate feedbacks accelerate global warming, P. Natl. Acad. Sci. USA, 108, 14769-14774, 2011.

Kutzbach, L., Wille, C., and Pfeiffer, E.-M.: The exchange of carbon dioxide between wet arctic tundra and the atmosphere at the Lena River Delta, Northern Siberia, Biogeosciences, 4, 869-890, doi:10.5194/bg-4-869-2007, 2007.

Kwon, M. J., Heimann, M., Kolle, O., Luus, K. A., Schuur, E. A. G., Zimov, N., Zimov, S. A., and Göckede, M.: Long-term drainage reduces $\mathrm{CO}_{2}$ uptake and increases $\mathrm{CO}_{2}$ emission on a Siberian floodplain due to shifts in vegetation community and soil thermal characteristics, Biogeosciences, 13, 4219-4235, doi:10.5194/bg13-4219-2016, 2016.

Lafleur, P. M. and Humphreys, E. R.: Spring warming and carbon dioxide exchange over low Arctic tundra in central Canada, Glob. Change Biol., 14, 740-756, 2007.

Lamb, E. G., Han, S., Lanoil, B. D., Henry, G. H. R., Brummell, M. E., Banerjee, S., and Siciliano, S. D.: A High Arctic soil ecosystem resists long-term environmental manipulations, Glob. Change Biol., 17, 3187-3194, 2011.

Lawrence, D. M., Slater, A. G., Romanovsky, V. E., and Nicolsky, D. J.: Sensitivity of a model projection of near-surface permafrost degradation to soil column depth and representation of soil organic matter, J. Geophys. Res.-Earth, 113, F02011, doi:10.1029/2007jf000883, 2008.

Liljedahl, A. K., Boike, J., Daanen, R. P., Fedorov, A. N., Frost, G. V., Grosse, G., Hinzman, L. D., Iijma, Y., Jorgenson, J. C., Matveyeva, N., Necsoiu, M., Raynolds, M. K., Romanovsky, V. E., Schulla, J., Tape, K. D., Walker, D. A., Wilson, C. J., Yabuki, H., and Zona, D.: Pan-Arctic ice-wedge degradation in warming permafrost and its influence on tundra hydrology, Nat. Geosci., 9, 312-318, doi:10.1038/ngeo2674, 2016.

Liu, H. P., Peters, G., and Foken, T.: New equations for sonic temperature variance and buoyancy heat flux with an omnidirectional sonic anemometer, Bound.-Lay. Meteorol., 100, 459-468, 2001.

Lloyd, J. and Taylor, J. A.: On the Temperature-Dependence of Soil Respiration, Funct. Ecol., 8, 315-323, 1994.

Lund, M., Falk, J. M., Friborg, T., Mbufong, H. N., Sigsgaard, C., Soegaard, H., and Tamstorf, M. P.: Trends in $\mathrm{CO}_{2}$ exchange in a high Arctic tundra heath, 2000-2010, J. Geophys. Res.-Biogeo., 117, G02001, doi:10.1029/2011JG001901, 2012.
Lupascu, M., Welker, J. M., Seibt, U., Maseyk, K., Xu, X., and Czimczik, C. I.: High Arctic wetting reduces permafrost carbon feedbacks to climate warming, Nature Climate Change, 4, 51-55, 2014.

Mack, M. C., Schuur, E. A. G., Bret-Harte, M. S., Shaver, G. R., and Chapin, F. S.: Ecosystem carbon storage in arctic tundra reduced by long-term nutrient fertilization, Nature, 431, 440-443, 2004.

Merbold, L., Kutsch, W. L., Corradi, C., Kolle, O., Rebmann, C., Stoy, P. C., Zimov, S. A., and Schulze, E. D.: Artificial drainage and associated carbon fluxes $\left(\mathrm{CO}_{2} / \mathrm{CH}_{4}\right)$ in a tundra ecosystem, Glob. Change Biol., 15, 2599-2614, 2009.

Moore, C. J.: Frequency response corrections for eddy correlation systems, Bound.-Lay. Meteorol., 37, 17-35, 1986.

Nordstroem, C., Soegaard, H., Christensen, T. R., Friborg, T., and Hansen, B. U.: Seasonal carbon dioxide balance and respiration of a high-arctic fen ecosystem in NE-Greenland, Theor. Appl. Climatol., 70, 149-166, 2001.

Oechel, W. C., Vourlitis, G., and Hastings, S. J.: Cold season $\mathrm{CO}_{2}$ emission from Arctic soils, Global Biogeochem. Cy., 11, 163 172, 1997.

Oechel, W. C., Vourlitis, G. L., Hastings, S. J., Ault, R. P., and Bryant, P.: The effects of water table manipulation and elevated temperature on the net $\mathrm{CO}_{2}$ flux of wet sedge tundra ecosystems, Glob. Change Biol., 4, 77-90, 1998.

Oechel, W. C., Laskowski, C. A., Burba, G., Gioli, B., and Kalhori, A. A. M.: Annual patterns and budget of $\mathrm{CO}_{2}$ flux in an Arctic tussock tundra ecosystem, J. Geophys. Res.-Biogeo., 119, 323339, 2014.

Olivas, P. C., Oberbauer, S. F., Tweedie, C. E., Oechel, W. C., and Kuchy, A.: Responses of $\mathrm{CO}_{2}$ flux components of Alaskan Coastal Plain tundra to shifts in water table, J. Geophys. Res.Biogeo., 115, G00i05, doi:10.1029/2009jg001254, 2010.

Parmentier, F. J. W., van der Molen, M. K., van Huissteden, J., Karsanaev, S. A., Kononov, A. V., Suzdalov, D. A., Maximov, T. C., and Dolman, A. J.: Longer growing seasons do not increase net carbon uptake in the northeastern Siberian tundra, J. Geophys. Res., 116, 2156-2202, 2011.

Payette, S., Delwaide, A., Caccianiga, M., and Beauchemin, M.: Accelerated thawing of subarctic peatland permafrost over the last 50 years, Geophys. Res. Lett., 31, doi:10.1029/2004GL020358, 2004.

Peterson, K. M., Billings, W. D., and Reynolds, D. N.: Influence of Water Table and Atmospheric $\mathrm{CO}_{2}$ Concentration on the Carbon Balance of Arctic Tundra, Arct. Alp. Res., 16, 331-335, 1984.

R Core Team: R: A Language and Environment for Statistical Computing, R Foundation for Statistical Computing, Vienna, Austria, 2014.

Reichstein, M., Falge, E., Baldocchi, D., Papale, D., Aubinet, M., Berbigier, P., Bernhofer, C., Buchmann, N., Gilmanov, T., Granier, A., Grunwald, T., Havrankova, K., Ilvesniemi, H., Janous, D., Knohl, A., Laurila, T., Lohila, A., Loustau, D., Matteucci, G., Meyers, T., Miglietta, F., Ourcival, J. M., Pumpanen, J., Rambal, S., Rotenberg, E., Sanz, M., Tenhunen, J., Seufert, G., Vaccari, F., Vesala, T., Yakir, D., and Valentini, R.: On the separation of net ecosystem exchange into assimilation and ecosystem respiration: review and improved algorithm, Glob. Change Biol., 11, 1424-1439, 2005

Rohde, R., Muller, R. A., Jacobsen, R., Muller, E., Perlmutter, S., Rosenfeld, A., Wurtele, J., Groom, D., and Wickham, C.: 
A New Estimate of the Average Earth Surface Land Temperature Spanning 1753 to 2011, Geoinfor. Geostat., 1, 1-7, doi:/10.4172/2327-4581.1000101, 2013.

Runkle, B. R. K., Sachs, T., Wille, C., Pfeiffer, E.-M., and Kutzbach, L.: Bulk partitioning the growing season net ecosystem exchange of $\mathrm{CO}_{2}$ in Siberian tundra reveals the seasonality of its carbon sequestration strength, Biogeosciences, 10, 1337-1349, doi:10.5194/bg-10-1337-2013, 2013.

Schaefer, K., Zhang, T., Bruhwiler, L., and Barrett, A. P.: Amount and timing of permafrost carbon release in response to climate warming, Tellus B, 63, 165-180, 2011.

Schuur, E. A. G., Bockheim, J., Canadell, J. G., Euskirchen, E., Field, C. B., Goryachkin, S. V., Hagemann, S., Kuhry, P., Lafleur, P. M., Lee, H., Mazhitova, G., Nelson, F. E., Rinke, A., Romanovsky, V. E., Shiklomanov, N., Tarnocai, C., Venevsky, S., Vogel, J. G., and Zimov, S. A.: Vulnerability of permafrost carbon to climate change: Implications for the global carbon cycle, Bioscience, 58, 701-714, 2008.

Serreze, M. C., Walsh, J. E., Chapin III, F. S., Osterkamp, T., Dyurgerov, M., Romanovsky, V., Oechel, W. C., Morison, J., Zhang, T., and Barry, R. G.: Observational evidence of recent change in the northern high-latitude environment, Climatic Change, 46, 159207, 2000.

Shaver, G. R., Billings, W. D., Chapin III, F. S., Giblin, A. E., Nadelhoffer, K. J., Oechel, W. C., and Rastetter, E. B.: Global Change and the Carbon Balance of Arctic Ecosystems, Bioscience, 42, 433-441, 1992.

Sistla, S. A., Moore, J. C., Simpson, R. T., Gough, L., Shaver, G. R., and Schimel, J. P.: Long-term warming restructures Arctic tundra without changing net soil carbon storage, Nature, 497, 615-618, 2013.

SWIPA: Snow, Water, Ice and Permafrost in the Arctic (SWIPA): Climate Change and the Cryosphere, Arctic Monitoring and Assessment (AMAP), AMAP, Oslo, Norway, 2011.
Tscharntke, T., Hochberg, M. E., Rand, T. A., Resh, V. H., and Krauss, J.: Author sequence and credit for contributions in multiauthored publications, Plos Biol., 5, 13-14, 2007.

van der Molen, M. K., van Huissteden, J., Parmentier, F. J. W., Petrescu, A. M. R., Dolman, A. J., Maximov, T. C., Kononov, A. V., Karsanaev, S. V., and Suzdalov, D. A.: The growing season greenhouse gas balance of a continental tundra site in the Indigirka lowlands, NE Siberia, Biogeosciences, 4, 985-1003, doi:10.5194/bg-4-985-2007, 2007.

Webb, E. K., Pearman, G. I., and Leuning, R.: Correction of flux measurements for density effects due to heat and water vapour transfer, Q. J. Roy. Meteor. Soc., 106, 85-100, 1980.

Zimov, N. S., Zimov, S. A., Zimova, A. E., Zimova, G. M., Chuprynin, V. I., and Chapin, F. S.: Carbon storage in permafrost and soils of the mammoth tundra-steppe biome: Role in the global carbon budget, Geophys. Res. Lett., 36, L02502, 2009.

Zimov, S. A., Davidov, S. P., Voropaev, Y. V., F., P. S., Semiletov, I. P., Chapin, M. C., and Chapin III, F. S.: Siberian $\mathrm{CO}_{2}$ efflux in winter as a $\mathrm{CO}_{2}$ source and cause of seasonality in atmospheric $\mathrm{CO}_{2}$, Climatic Change, 33, 111-120, 1996.

Zona, D., Oechel, W. C., Kochendorfer, J., U, K. T. P., Salyuk, A. N., Olivas, P. C., Oberbauer, S. F., and Lipson, D. A.: Methane fluxes during the initiation of a large-scale water table manipulation experiment in the Alaskan Arctic tundra, Global Biogeochem. Cy., 23, Gb2013, 2009.

Zona, D., Oechel, W. C., Peterson, K. M., Clements, R. J., Paw, U. K. T., and Ustin, S. L.: Characterization of the carbon fluxes of a vegetated drained lake basin chronosequence on the Alaskan Arctic Coastal Plain, Glob. Change Biol., 16, 1870-1882, 2010.

Zona, D., Lipson, D. A., Paw, K. T., Oberbauer, S. F., Olivas, P., Gioli, B., and Oechel, W. C.: Increased $\mathrm{CO}_{2}$ loss from vegetated drained lake tundra ecosystems due to flooding, Global Biogeochem. Cy., 26, Gb2004, 2012. 